\title{
POGLED NA INDIKATORJE - KAZALCE ZA MERJENJE TRAJNOSTNEGA RAZVOJA
}

\author{
Ana Vovk Korže \\ Univerza v Mariboru, Filozofska fakulteta, Koroška c. 160, \\ SI - 2000 Maribor, Slovenija \\ e-mail: ana.vovk@uni-mb.si
}

Izvirni znanstveni članek

COBISS 1.01

\section{Izvleček}

Indikatorji trajnostnega razvoja prikazujejo statistične vrednosti, ki merijo kapaciteto celotnega sistema za zadovoljevanje potreb današnjih in prihodnjih generacij. Indikatorji kažejo stanje in trende, kako se premikamo proti zastavljenim ciljem. So orodje s katerim merimo napredek. Namenjeni so različnim uporabnikom: širši javnosti, politikom, strokovni javnosti, zato morajo biti pripravljeni tako, da predstavljajo poenostavljene informacije, ki so relevantne za doseganje trajnostnega razvoja.

Ključne besede: okolje, trajnostni razvoj, indikator, okoljsko upravljanje, strategija razvoja.

\section{VIEW ON THE INDICATORS -FINGER FOR MEASURES OF SUSTAINABLE DEVELOPMENT}

\begin{abstract}
The indicators of sustainable development show the statistic values that measure the capacity of integral system for contentment of the needs for present and future generations. The indicators show the situation and the guidelines, how we pursue our goals. They are tools for progress measuring. They are meant for different users: the broader public, politicians, professionals, therefore they have to be prepared in a way to represent simplified information, which are relevant for reaching sustainable development.
\end{abstract}

Key words: environment, sustainable development, indicator, environmental management, development strategy. 


\section{UVOD}

Beseda indikator pomeni v prevodu kazalec (Veliki slovar tujk, str. 492) in se uporablja v slovenskem jeziku tako v prevodu (torej kazalec) kakor tudi v originalu (beseda je latinskega izvora). Kljub težnji, da naj bi v Sloveniji uporabljali kar se da največ slovenskih izrazov menimo, da je v primeru »indikator ali kazalec« bolj umestno uporabljati izbirno latinsko besedo, ker pri pridevniški obliki samostalnika kazalec ne najdemo ustrezne slovenske oblike, za razliko od latinske besede indikator - indikatorski. To je en razlog, da v prispevku uporabljamo besedo indikator, drugi razlog pa je v mednarodni terminologiji, ki enotno uporablja besedo »indikator« tako v nemškem kot angleškem govornem območju (zaradi pregleda literature iz teh govornih območij se omejujemo le na ti dve).

Indikator je v literaturi poimenovan kot temeljna enota informacijskega sistema varstva okolja. Definiran je kot sintezna spremenljivka, pridobljena iz dveh ali več podatkov (EEA 1998 , 2). Podatek je lastnost pojava, ki se meri ali opazuje, indikator pa ima pomen, ki presega sporočilnost podatka. Indikator je razvit za vnaprej določen namen. Okoljski indikatorji povezujejo podatke, ki kažejo okoljske pritiske in njihove vzroke, okoljske razmere in odzive na njih. Med okoljske indikatorje se štejejo tudi indikatorji trajnostnega razvoja. Zato lahko indikatorje trajnostnega razvoja opredelimo kot okoljske indikatorje, ki so oblikovani za potrebe preusmerjanja rasti k trajnosti (Radej 1998, 11).

Slika 1: Okoljske indikatorje lahko delimo v tri skupine (Radej 1998)

Picture 1: Ecological indicators can be sperated in three gropus (Radej 1998)
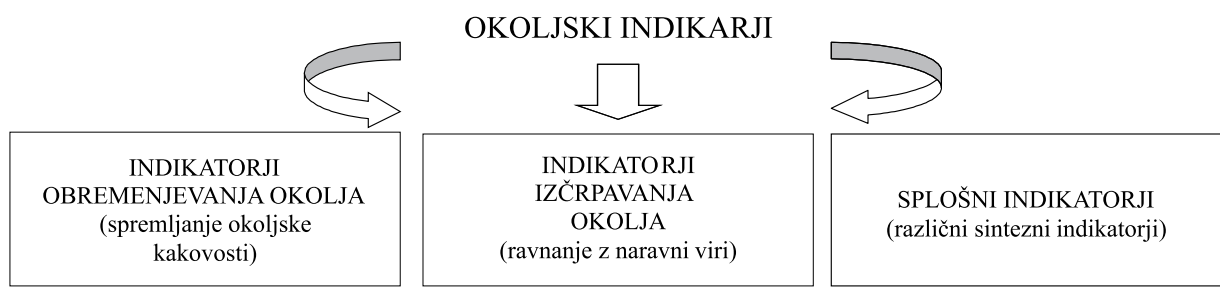

Indikatorji obremenjevanja okolja vključujejo podatke s področja spremljanja stanja pokrajinskih sestavin, prebivalstva, dejavnosti in okolja in se pojavljajo kot nosilni nizi podatkov. Indikatorji izčrpavanja okolja zajemajo ravnanje z naravnimi viri. Splošni indikatorji pa povezujejo različne zbrane podatke o okolju. Indikatorje, ki šele z uporabo postanejo okoljski, imenujemo splošni okoljski indikatorji. V skupino splošnih indikatorjev spadajo tudi ekonomski, ki se uporabljajo za okoljske namene.

Indikator je torej okoljski, če se uporablja za interpretacijo okoljskih procesov.

Indikatorji trajnostnega razvoja spadajo med sisteme indikatorjev, ki se uporabljajo za spremljanje okoljske kakovosti gospodarske rasti (sem spadajo še OECD indikatorji, indikatorji Evropske okoljske agencije EEA za pripravo poročila o stanju okolja, indikatorji SOIA (Alpska konvencija) in indikatorji METAP (varstvo Sredozemskega morja). 
O indikatorjih obstaja obsežna literatura. V magistrskem delu Katje Vintar (mentor dr. D. Plut) z naslovom Okoljevarstveni vidiki sonaravnega regionalnega razvoja Slovenije (2003) so v prvem delu zelo natančno predstavljeni indikatorji sonaravnega razvoja, v drugem pa njihova uporaba na primeru slovenskih statističnih regij. Indikatorji sonaravnega razvoja so razvrščeni v tri skupine (ekonomski, socialni, okoljski) ter vsaka od teh skupin še na dva nivoja in sicer osnovni in dopolnilni.

Namen prispevka je osvetliti dva pojma, to je indikator in trajnostni razvoj, saj se obe besedni zvezi zelo pogosto uporabljata, mnogokdaj pa vidimo, da je zlasti trajnostni razvoj razumljen precej različno, posledično pa seveda tudi njegovi indikatorji.

\section{RAZUMEVANJE TRAJNOSTNEGA RAZVOJA}

Priporočila Komisije za celostno okoljsko upravljanje so opis procesa in opomnik o ključnih elementih, ki naj bi se upoštevali pri pripravi programa celostnega okoljskega upravljanja na lokalni ravni (Integrated Environmental Management Program). Namen priporočil je pomagati lokalnim oblastem pri vzpostavljanju sistema celostnega okoljskega upravljanja za to, da se izboljša stanje okolja.

Slika 2: Dimenzije trajnostnega razvoja presegajo samo okoljsko, ekonomsko in socialno plat (prirejno po: Hans-Dietrich Hass, Dieter Matthew Schlesinge 2007, 14)

Picture 2: Dimension the sustainable development can over achieve ecological, economical and social issue

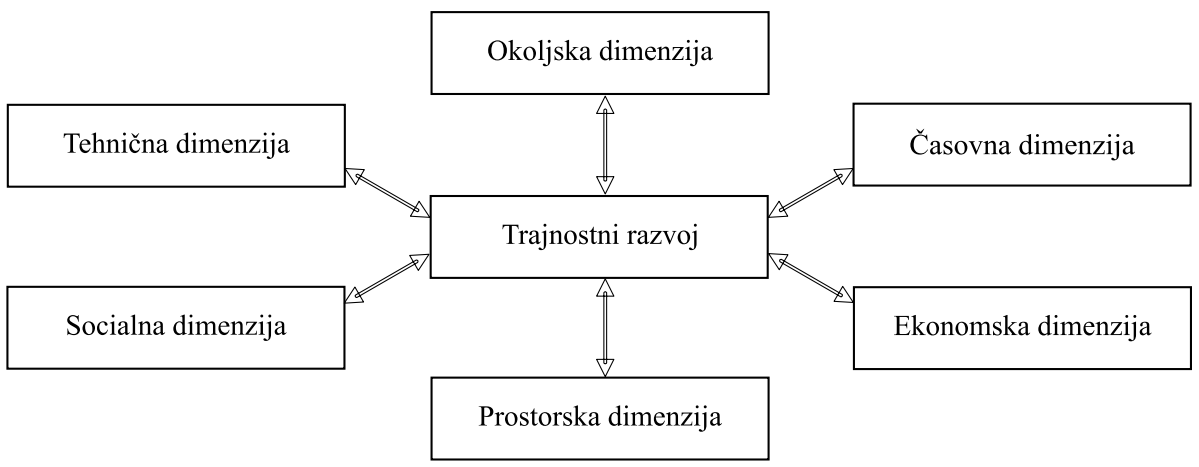

Leta 1992 se je z dvema dokumentoma, to je Deklaracijo iz Ria (Rio Declaration on Environment and Development 1992) in Agendo 21 (Agenda 21: Programme of Action for Sustainable Development 1992) začel udejanjati trajnostni razvoj. Temelje za procese v Riu so postavili leta 1972 na svetovni konferenci o človekovem okolju v Stockholmu. Leta 1983 so v okviru Združenih narodov ustanovili Svetovno komisijo za okolje in razvoj (t.i. Brundtlandovo komisijo), ki je opredelila definicijo trajnostnega razvoja: »Trajnostni razvoj je razvoj, ki zadovoljuje potrebe sedanje generacije, ne da pri tem ogrozil zmožnost prihodnjih 
generacij, da bi zadovoljevala svoje potrebe« (Polak 2006). Osnovna misel tega modela ni, da je treba storiti vse, da bo vedno šlo tako kot danes, pač pa, da človeštvo ne sme z naravo početi tega, kar počne danes, če noče izzvati hudih in nerešljivih ekoloških, socialnih in političnih problemov in celo ogroziti svojega obstoja.

Sporočila s konferenc o okolju so jasno podčrtala, da gospodarskega razvoja zaradi velikih okoljskih onesnaženj ne moremo ustaviti, da pa moramo spremeniti njegovo smer, da bo manj uničujoč za okolje. Pomembna je bila ugotovitev, da si moramo varstvo okolja in doseganje trajnostnega razvoja deliti kot skupno odgovornost, pri tem pa so potrebne korenite spremembe, če želimo spremeniti netrajnostne vzorce proizvodnje in potrošnje. Koncept gospodarske rasti, kakršno poznamo danes, je nezdružljiv s konceptom trajnostnega razvoja, za katerega je potrebno ravnovesje v družbi in okolju. Za uresničitev načel in sporazumov iz Ria je bil pripravljen program ukrepov, bolj znan pod imenom Agenda 21, ki poziva vlade vseh držav, naj sprejmejo nacionalne strategije trajnostnega razvoja. Glavne usmeritve Agende 21 lahko povežemo v štiri cilje:

1. trajnost življenjskega prostora in okolja,

2. financiranje lokalnih razvojnih politik, inštitucij in ustvarjanje novih kapacitet,

3. integracija strategij za izboljšanje življenjskega standarda in trajnostnega upravljanja okolja in

4. izvajanje nacionalnih planov in financiranje ruralnih in slabo razvitih urbanih območij ter pomoč šibkejšim.

$\mathrm{V}$ pomoč implementaciji trajnostnega razvoja na nacionalnem, regionalnem in lokalnem nivoju je bila ustanovljena Komisija Združenih narodov za trajnostni razvoj (United Nations Commison for Sustainble Development - UNCSD). Ta je v letu 1996 lansirala večletni testni program (Earth Summit +5: Programme for the Further Implementation of Agenda 21. United Nations, 1997. Indicators of sustainable devlopment - A pilot study following the methodology of the United Nations Commisssion on Sustainble Development. European Communities, Luxenbourg, 1998 z namenom razširiti nivo tovrstnih znanj. V raziskovalnih programih je bilo vključenih tudi šest držav članic Evropske unije (Avstrija, Belgija, Finska, Francija, Nemčija in Anglija). Rezultat tega pristopa je bil dejansko večja stopnja sonaravnega razvoja v teh državah, predvsem višja zavest odnosa do okolja.

Trajnostni razvoj je v 90-ih letih postal normativno vodilo okoljske politike v EU. V 5. akcijskem programu $(1992$ - 1999) je trajnostni razvoj izrecno opredeljen kot način vključevanja okoljske dimenzije $\mathrm{v}$ vse sektorje. Nov pristop je bil usmerjen v dogovarjanje in doseganje konsenza med vsemi akterji na tem področju. Tudi v Amsterdamski pogodbi (Treaty of Amsterdam, 1997) je bil trajnostni razvoj potrjen kot prednostna naloga s skupnim ciljem povezovanja okoljske, ekonomske in socialne politike $\mathrm{z}$ definiranimi ukrepi za njegovo pot (nadzor porabe naravnih virov, preusmeritev sedanje politike subvencioniranja kmetijstva, prometa, energetike $\mathrm{v}$ bolj trajnostno smer, sprememba davčne politike v smer obdavčenja porabe naravnih virov, postavitev visokih tehnoloških standardov).

Napredek v strategiji trajnostnega razvoja pomeni sprejetje EU Strategije trajnostnega razvoja (A Sustainable for a better World 2001) na vrhu Evropskega sveta v Gothenburgu junija 2001. Prvi korak je bila identifikacija stanja po prioritetnih področjih (podnebne spre- 
membe, promet, zdravje in naravne danosti - viri) s pripadajočimi cilji in smernicami. V letu 2002 je komisija predstavila še Sporočilo Komisije o eksternih dimenzijah trajnostnega razvoja. Poudarja, da morajo gospodarski razvoj, socialni razvoj in varstvo okolja delovati skladno.

Slika 3: Shema uravnoteženosti socialnega gospodarskega in okoljskega razvoja Picture 3: Chart includes social, economical and ecological development

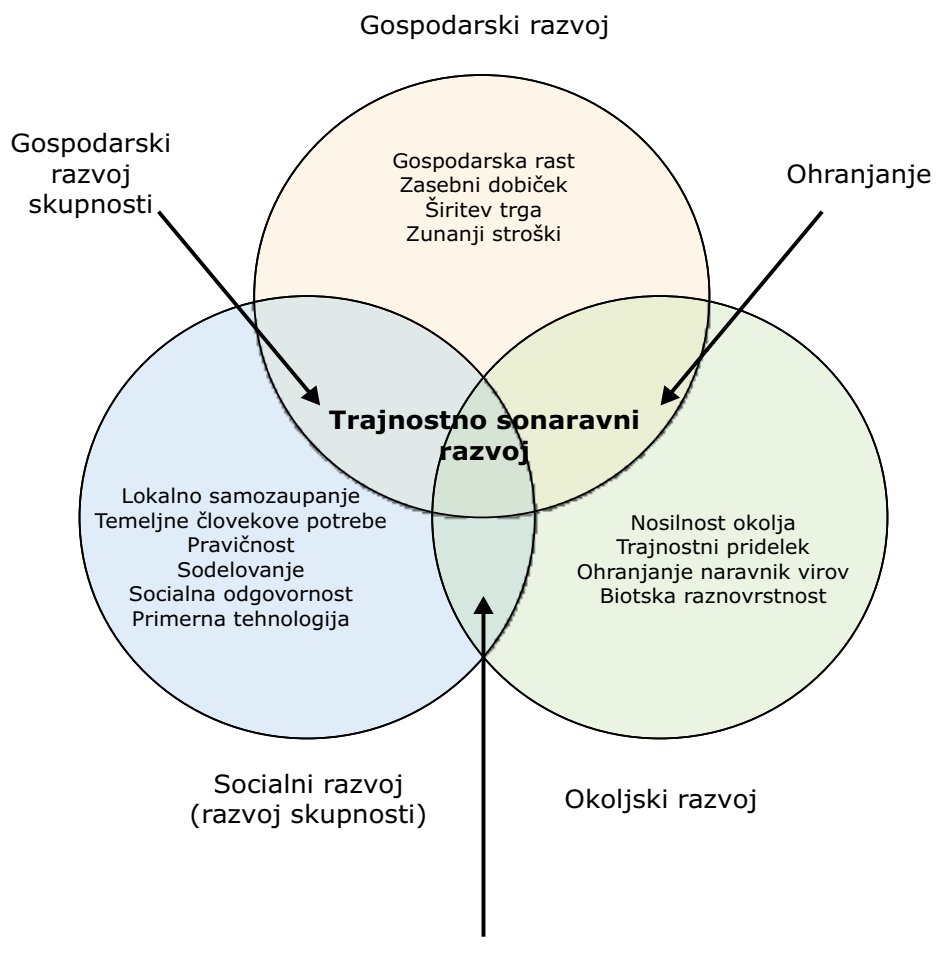

Globoka ekologija

Vir: European common indicators - towerds a local sustainability profil 2000.

V Bruslju je bila leta 2005 sprejeta Prenovljena Strategija za trajnostni razvoj (Towards a global partnership for sustainable development, COMMUNICATION FROM THE COMMISSION, Brussels COM(2002)82). Zajema principe evropske politike na vseh področjih. Eden od ciljev EU Strategije za trajnostni razvoj je spodbuditi lokalne skupnosti, da se v okviru trajnostnega razvoja bolj zavzeto lotevajo razreševanja urbanih problemov, med njimi tudi gospodarskih in socialnih, ne samo okoljskih.

Septembra 2002 je v Johannesburgu potekal drugi Vrh o trajnostnem razvoju (v nadaljevanju WSSD) (Johannesburg Plan of Implementation of the World Summi on Sustainble 
Development, UN, 4. avgust 2002). Na srečanju so obravnavali naslednja področja: voda in izboljšanje zdravstvenih razmer, energija, segrevanje ozračja, naravni viri in biološka raznolikost, trgovina, človekove pravice in upravljanje, zdravje. Državam so priporočili takojšnje ukrepanje z namenom nadgraditi pripravo in izdelavo nacionalnih strategij za trajnostni razvoj kot tudi implementiranje le teh do leta 2005. Na Svetovnem vrhu (2002) v Johanesburgu so predstavniki lokalnih skupnosti z vsega sveta in tudi predstavniki Programa Združenih narodov za razvoj (UNDP) in Svetovne zdravstvene organizacije (WHO) vključno z ICLEI (The International Council for Local Environmental Initiatives) pripravili oz. sprožili nov progam Lokalna akcija (Local Action 21) kot nadgradnjo Lokalne agende 21 (Local Agenda 21).

Lokalna akcija 21 je globalni mandat lokalnim oblastem za premik od Agende k aktivnostim, ki pospešujejo implementacijo trajnostnega razvoja.

Šesti okoljski akcijski program (6. EAP) je pozval k pripravi Tematske strategije za urbano okolje (2006) s ciljem, prispevati s celostnim pristopom k visoki kakovosti življenja in socialni blaginji državljanov z zagotavljanjem okolja, v katerem stopnja onesnaženosti ne vpliva škodljivo na zdravje ljudi in okolje ter spodbujanjem trajnostnega urbanega okolja. Strategijo je evropska Komisija sprejela januarja, potrjena je bila na okoljskem svetu junija 2006. Leta 2007 je Komisija k urbani strategiji izdala še Priporočila za celostno okoljsko upravljanje in Trajnostni načrt za urbani promet (2007).

Trajnostni urbani razvoj zahteva celostni pristop, tematska strategija za urbano okolje pa se zavzema za to, da državne in regionalne oblasti podprejo lokalne skupnosti, da dosežejo bolj celostno upravljanje na lokalni ravni. Prebivalci urbanih območij, njihova kakovost življenja in kakovost okolja so odvisni od izgleda in funkcije mest. Za zagotavljanje kakovosti življenja v urbanih območjih potrebujemo celostne razvojne strategije.

Urbana območja se soočajo z velik številom okoljskih izzivov. Identificiramo lahko niz skupnih problemov, kijih imajo mesta: slaba kakovostzraka, povečan obseg prometa, prometni zamaški, hrup, pomanjkanje območij za šport, rekreacijo, propadajoče stavbe, visoke ravni emisij toplogrednih plinov, spalna naselja, ustvarjanje ogromnih količin odpadkov in odplak. Ti izzivi so resni in imajo velik vpliv na zdravje, okolje in gospodarstvo.

\section{RAZVOJ IN UPORABA INDIKATORJEV V SVETU}

Zaradi uspešnih primerov dobre prakse se želimo nasloniti tudi na spoznanja iz tujine (ugotovitve v slovenskem prostoru upoštevamo kot pomembne vhodne podatke). Razlog, da je tematika o okoljskih indikatorjih aktualna, izhaja iz obveznosti, ki jih ima vlada RS in nekatera ministrstva $\mathrm{v}$ skladu z Zakonom o varstvu okolja (73. - 75. člen), članstva v EU (za evidence o okoljsko relevantnih procesih (Eurostat 1998), vključitvijo v aktivnosti Ekonomske komisije ZN za Evropo in ostalimi mednarodnimi obveznosti (kot npr. Agenda 21 o oblikovanju trajnostnega razvoja $\mathrm{v}$ praksi, v lokalnem in regionalnem okviru).

$\mathrm{Z}$ razvojem okoljskih indikatorjev se ukvarjajo tri mednarodne organizacije:

a) OECD Organizacija za ekonomsko sodelovanje in razvoj: od leta 1985 naprej vsake 2 leti izdaja zgoščenko okoljskih podatkov Compendium of Environmental Data in v njej 
objavlja 100 okoljskih indikatorjev za članice OECD (po tem pristopu se v Sloveniji pripravlja pregled okoljskih dogajanj). OECD-jevo jedro okoljskih indikatorjev ponuja minimalen, a med državami usklajen in primerljiv pogled na indikatorje stanja, razmer onesnaževanja in odzivov. Jedro okoljskih indikatorjev je razvito za potrebe Pregleda okoljskega dogajanja. Jedro vsebuje 14 skupin indikatorjev, od tega jih je 9 usmerjenih na prikaz onesnaževanja okolja, 4 skupine prikazujejo indikatorje o naravnih virih, ena skupina indikatorjev pa je splošna.

b) Po letu 1992 je Komisija za trajnostni razvoj United Nations Commission of Sustainable Development UNCSD pod ZN razvila 130 okoljskih indikatorjev in jih uporablja za spremljanje napredka pri spremljanju ciljev konference iz Ria. UNCSD pregleduje poročila o izvajanju nalog iz Agende 21, ki jih za te namene pripravljajo v ZN ali vlade držav, ki so bile udeležene na konferenci leta 1992. Okoljski indikatorji UNCSD naj bi dali javnosti večjo možnost preverjati napredek pri razvoju nalog, prevzetih v Riu tudi na nacionalnem področju. Leta 1996 je bil objavljen okvir za pripravo indikatorjev trajnostnega razvoja. Uvajanje indikatorjev trajnostnega razvoja v prakso je vključevalo tudi preizkušanje liste indikatorjev UNCSD. Kot testne države so se prijavile Avstrija, Belgija, Češka, Finska, Francija, Nemčija in Velika Britanija. V delovni listi indikatorjev trajnostnega razvoja so razvrščeni le-ti v tri skupine, in sicer indikatorji gonilnih sil, indikatorji stanja in indikatorji odzivov.

c) Leta 1998 je EEA Okoljska evropska agencija pripravila sistem z več kot 200 okoljskimi indikatorji in jih uporabila za oblikovanje poročila o stanju okolja leta 1998. Slovenija pri razvoju okoljskih indikatorjev poudarja sistem EEA in zato je njenemu indikatorskemu sistemu namenjene največ pozornosti. EU je razvila svoj sistem indikatorjev, kar je opazno v poročilih o stanju okolja v Evropi. Ti kazalci so najbolj dodelani in jih je možno uporabljati tudi kot podporo bodočim odločitvam. Pomembno vlogo v okoljskem poročanju in pri izdelavi okoljskih indikatorjev ima Evropska okoljska agencija.

Indikatorji socialnih vidikov so namenjeni spremljanju uresničevanja nalog iz Ria: boj proti revščini, umiritev demografskih gibanj, promocija izobraževanja, zdravja, bivanja.

Ekonomski vidiki trajnostnega razvoja se odsevajo v naslednjih skupinah: spreminjanje potrošniških navad, finančni viri in mehanizmi, prenos okolju prijazne tehnologije.

Indikatorji okoljskih vidikov obravnavajo problematiko rabe vode, tal in drugih naravnih virov, problematiko obremenjevanja okolja.

Indikatorji institucionalnih vidikov trajnostnega razvoja vključujejo integriranost politik in odločanja, krepitev ključnih skupin varstva okolja in informiranje.

Slovenija sodeluje tudi v nekaterih regionalnih projektih razvoja okoljskih indikatorjev. Čeprav izhajajo iz pristopov OECD, UNCSD in EEA dodajajo specifične indikatorje za posamezno področje (kot npr. sistem indikatorjev v okviru Alpske konvencije in v projektu zaščite Sredozemlja). Slovenija sodeluje tudi v specializiranih projektih razvoja indikatorjev kot so CORINAIR ali IPPC - družina indikatorjev, usmerjenih v zrak, $\mathrm{CO}_{2}$ ali EIONET - logistična podpora razvoju indikatorjev. 


\section{UPORABA OKOLJSKI INDIKATORJEV V SLOVENIJI}

Okoljski indikatorji, pripravljeni za pregled okoljskega dogajanja v Sloveniji so najbolj obsežna primerjava Slovenije z drugimi državami članicami OECD. Pripraviti je bilo potrebno tudi Poročilo o izvajanju sklepov UNCED ter se vključiti v projekt testiranja 45tih okoljskih kazalcev po shemi kazalcev UNCSD. Slovenija se je vključila tudi v mreže okoljskih informacij EIONET, v Alpsko konvencijo in pripravlja poročilo o stanju okolja.

Statistične evidence za proučevanje okoljskega delovanja objavljajo Statistični urad RS (Statistični letopis), MOP (Poročilo o stanju okolja) in ostale redne publikacije organov, Ministrstvo za finance izdaja Bilten MF in Poročevalec Državnega zbora.

Tudi lokalne skupnosti imajo pri produkciji okoljskih podatkov pomembno vlogo. Mestne občine imajo lokalne sisteme za monitoringe. Komunalna podjetja izdajajo poročila o delu in poslovne načrte.

Indikatorji EU 98 se zelo razlikujejo po načinu izražanja sprememb. Izraženi so kot:

1. absolutna števila (podatkovni nizi, npr. število prebivalcev);

2. relativna števila (to so enostavni indikatorji, npr. trend energetske intenzivnosti in je količnik med dvema podatkovnima nizoma);

3. družina indikatorjev (npr. demografski indikatorji);

4. bilančni indikatorji, ki so kompleksni kot npr. izdatki za varstvo okolja ali BDP;

5. tekstualni in slikovni indikatorji (kot npr. ukrepi za izboljšanje enegetske učinkovitosti).

Preglednica 1: Indikatorji za merjenje razvoja družbe - socialni steber trajnostnega razvoja Table 1: The indicators for measuring social development - socialpost of the sustainble development

\begin{tabular}{|l|l|l|}
\hline Ime kazalca & Opis & Vir informacije \\
\hline \multirow{2}{*}{} & $\begin{array}{l}\text { Stopnja populacijske rasti (stopnja umrljivosti, stopnja } \\
\text { rodnosti) }\end{array}$ & $\begin{array}{l}\text { Statistični urad Republike } \\
\text { Slovenije - SURS }\end{array}$ \\
\cline { 2 - 3 } & $\begin{array}{l}\text { Stopnja zaposlenosti } \\
- \text { glede na starost } \\
- \text { glede na spol } \\
- \text { število zaposlenih žensk na sto zaposlenih moških }\end{array}$ & SURS \\
\cline { 2 - 4 } & $\begin{array}{l}\text { Samozaposlenost } \\
\text { - delež samozaposlenih oseb }\end{array}$ & SURS (anketa o delovni sili) \\
\cline { 2 - 4 } & $\begin{array}{l}\text { Koeficient vključenih v šolanje } \\
-\% \text { prebivalstva s končano OŠ } \\
\text { - \% prebivalstva s končano SŠ, } \\
\text { - \% prebivalstva s končano visoko oz. višjo šolo } \\
\text { - Razlika med moškimi in ženskimi vključenimi } \\
\text { v izobraževanje }\end{array}$ & SURS \\
\hline
\end{tabular}




\begin{tabular}{|c|c|c|}
\hline $\begin{array}{l}\stackrel{0}{0} \\
\frac{0}{n} \\
\stackrel{D}{0} \\
0 \\
0 \\
0\end{array}$ & $\begin{array}{l}\text { A1 Zadovoljnost občanov z občino } \\
\text { * OBVEZNI SKUPNI EVROPSKI INDIKATOR } \\
\text { - zadovoljstvo z občino, } \\
\text { - storitvami, } \\
\text { - naravnim okoljem, } \\
\text { - urbanim okoljem } \\
\text { - varnostjo } \\
\text { - zaposlitvenimi možnostmi } \\
\text { - stanovanjskim standardom } \\
\text { - možnost sodelovanja pri odločanju... }\end{array}$ & Anketa, delavnice \\
\hline $\begin{array}{l}\text { Vseživljenjsko } \\
\text { učenje }\end{array}$ & $\begin{array}{l}\text { Število oseb, ki so se glede na starost udeležili } \\
\text { izobraževanja in usposabljanja }\end{array}$ & \\
\hline \multirow[b]{6}{*}{ 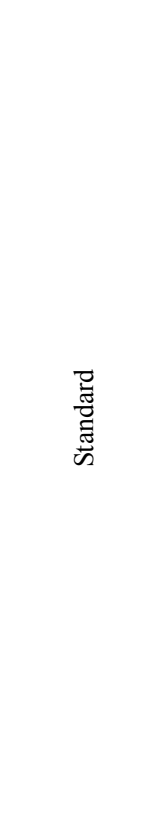 } & Število osebnih vozil na 100 prebivalcev & SURS \\
\hline & Število mobilnih telefonov na 100 prebivalcev & Telefonski operaterji \\
\hline & Število gospodinjstev, priključenih na internet & Internetni operaterji \\
\hline & Povprečna plača & SURS \\
\hline & Razlika med žensko in moško povprečno plačo & SURS \\
\hline & 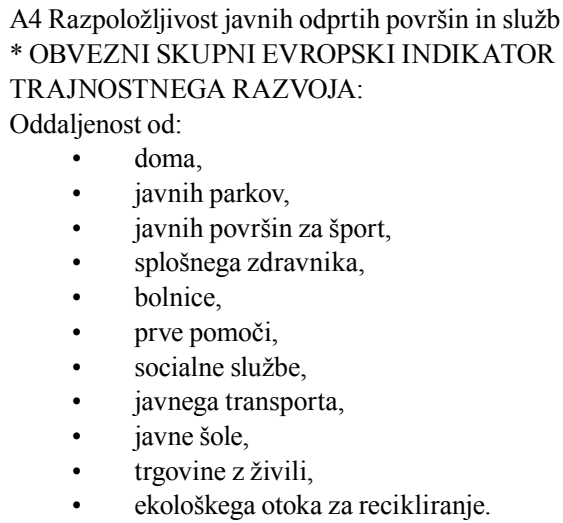 & Anketa \\
\hline
\end{tabular}

Indikatorji za merjenje gospodarskega razvoja (gospodarska rast, zasebni dobiček, širitev trga ...) v občini nam bodo pokazali gospodarsko dejavnost, razvitost občine in vpliv gospodarstva na okolje in stabilnost družbe. 
Preglednica 2: Indikatorji gospodarskega razvoja

Table 2: The indicators economical development

\begin{tabular}{|c|c|c|}
\hline Ime kazalca & Opis & Vir informacije \\
\hline \multirow[t]{2}{*}{ Raba tal } & 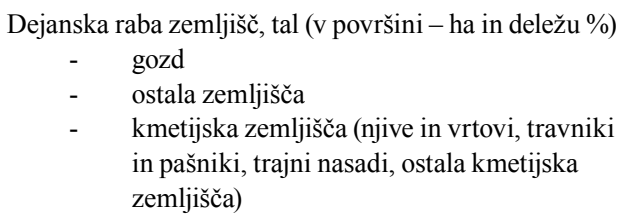 & $\begin{array}{l}\text { Katastrski načrti, geodetske } \\
\text { uprave, kmetijski inštituti }\end{array}$ \\
\hline & $\begin{aligned} & \text { Površina gozda, lesna zaloga, prirastek in posek } \\
& \text { - } \text { površina gozda }(000 \mathrm{ha}) \\
&- \text { lesna zaloga } \\
&- \text { prirastek } \\
& \text { - } \text { posek } \\
& \text { - } \text { posek v primerjavi z letnim prirastkom* brez } \\
& \text { površin v zaraščanju }\end{aligned}$ & SURS \\
\hline $\begin{array}{l}\text { Gospodarski } \\
\text { razvoj občine }\end{array}$ & $\begin{array}{l}\text { Razporeditev bruto domačega proizvoda (kmetijstvo, } \\
\text { industrija, terciarni in kvartarni sektor) } \\
\text { - izdatki za varstvo okolja ali druge investicije }\end{array}$ & SURS \\
\hline \multirow{7}{*}{ Kmetijstvo } & Uporaba pesticidov & $\begin{array}{l}\text { Kmetijski inštitut Slovenije, } \\
\text { Sanitarna uprava RS }\end{array}$ \\
\hline & $\begin{array}{l}\text { Raba gnojil (mineralnih, živinskih) na hektar kmetijskih } \\
\text { zemljišč } \\
\text { Velikost kmetijskih gospodarstev } \\
\begin{array}{l}\text { - } \quad \text { v kmetijskih površinah (ha) } \\
\text { - } \quad \text { glavi živine }\end{array}\end{array}$ & $\begin{array}{l}\text { Kmetijski inštitut Slovenije, } \\
\text { Sanitarna uprava RS }\end{array}$ \\
\hline & Starostna struktura gospodarjev & SURS \\
\hline & $\begin{array}{c}\text { Usposobljenost in izobraženost gospodarjev na kmetijah } \\
-\quad \text { izobrazba gospodarjev kmetij } \\
-\quad \text { kmetijska izobrazba }\end{array}$ & $\begin{array}{l}\text { SURS - Strukturni popis } \\
\text { gospodarstev }\end{array}$ \\
\hline & $\begin{array}{l}\text { Velikost kmetijskih gospodarstev } \\
\begin{array}{ll}-\quad & \text { v kmetijskih površinah (ha) } \\
- & \text { glav živine }\end{array}\end{array}$ & SURS \\
\hline & Število kmetijskih gospodarstev & SURS \\
\hline & $\begin{array}{cl}\text { Kmetije } \mathrm{z} \text { dodatnim virom dohodkov } \\
-\quad \text { gospodarji z glavnim nekmetijskim virom } \\
& \text { dohodka } \\
- & \text { z dopolnilnim nekmetijskim dohodkom } \\
- & \text { dohodek izključno od kmetijstva }\end{array}$ & SURS, EUROSTAT \\
\hline
\end{tabular}




\begin{tabular}{|c|c|c|}
\hline \multirow{6}{*}{ Kmetijstvo } & $\begin{array}{cl}\text { Kmetije z dodatnim virom dohodkov } \\
-\quad \text { gospodarji z glavnim nekmetijskim virom } \\
& \text { dohodka } \\
- & \text { z dopolnilnim nekmetijskim dohodkom } \\
- & \text { dohodek izključno od kmetijstva }\end{array}$ & \\
\hline & Najpomembnejše dopolnilne dejavnosti & MKGP \\
\hline & $\begin{array}{l}\text { Kmetijska zemljišča z omejenimi dejavniki za kmetijsko } \\
\text { pridelavo }\end{array}$ & MKGP \\
\hline & $\begin{array}{cl}\text { Ekološko kmetovanje } \\
-\quad \text { število gospodarstev z ekološkim } \\
\quad \text { kmetijstvom } \\
-\quad \text { število certifikatov } \\
-\quad \text { površina zemljišč z ekološkim kmetijstvom } \\
\quad \text { (ha) }\end{array}$ & $\begin{array}{l}\text { MKGP, Zveza ekoloških } \\
\text { kmetij Slovenije }\end{array}$ \\
\hline & $\begin{array}{l}\text { Kmetijska zemlja, namenjena proizvodnji obnovljivih } \\
\text { virov energije (energetske rastline, rastline za biomaso) }\end{array}$ & DG AGRI \\
\hline & $\begin{array}{l}\text { Vključenost v izvajanje okolju prijaznih kmetijskih } \\
\text { praks } \\
\text { - površine kmetijske zemlje v rabi }\end{array}$ & $\begin{array}{l}\text { MKGP, ARSKTRP } \\
\text { (subvencijske vloge) }\end{array}$ \\
\hline Transport & $\begin{array}{cl}\text { A3 } & \text { Lokalna mobilnost in transport ljudi } \\
- & \text { namen potovanja, } \\
- & \text { način potovanja, } \\
- & \text { porabljen čas }(\mathrm{min}) \\
- & \text { razdalja }(\mathrm{km}) \\
\text { OBVEZNI SKUPNI * EVROPSKI INDIKATOR }\end{array}$ & anketa \\
\hline
\end{tabular}

Preglednica 3: Indikatorji okoljske komponente trajnostnega razvoja:

Table 3: The indiacotrs for ecological components of sustainble development

\begin{tabular}{|c|c|c|}
\hline Ime kazalca & Opis & Vir informacije \\
\hline \multirow{2}{*}{ Potrošništvo } & Letna potrošnja energije na prebivalca & SURS \\
\hline & Letna potrošnja vode na prebivalca & Vodovod Maribor \\
\hline \multirow{2}{*}{ Zdravje } & Dostopnost do varne pitne vode & $\begin{array}{l}\text { Monitoring pitne vode, } \\
\text { meritve na vodonosnikih; } \\
\text { monitoring podzemne vode }\end{array}$ \\
\hline & $\begin{array}{l}\text { Ustreznost pitne vode } \\
\text { - koncentracije pesticidov v črpališčih, vodnih zajetjih }\end{array}$ & $\begin{array}{l}\text { Monitoring pitne vode, } \\
\text { meritve na vodonosnikih; } \\
\text { monitoring podzemne vode }\end{array}$ \\
\hline Zemljišča, območja & $\begin{array}{cc}\text { Razmerje med podeželjem in urbanim okoljem } \\
\text { - } & \% \text { prebivalstva, ki živi na podeželju } \\
\text { - } & \% \text { prebivalstva, ki živi v mestu } \\
\text { - } & \text { gostota prebivalstva } \\
\text { - } & \text { površina na prebivalstva }\end{array}$ & SURS \\
\hline
\end{tabular}




\begin{tabular}{|c|c|c|}
\hline & $\begin{array}{cl}\text { B9 Trajnostna raba tal } \\
-\quad & \text { delež umetnih površin v občini } \\
- & \text { zapuščene površine }\left(\mathrm{m}^{2}\right) \\
- & \text { kontaminirane površine }\left(\mathrm{m}^{2}\right) \\
- & \text { število prebivalcev } / \mathrm{km}^{2} \text { na urbanih } \\
& \text { površinah } \\
- & \text { rehabilitacije zapuščenih in } \\
& \text { kontaminiranih površin }\left(\mathrm{m}^{2}\right) \\
- & \text { obnova zapuščenih stavb }\left(\mathrm{m}^{2}\right) \\
- & \text { rehabilitacija zapuščenih površin }(\mathrm{za} \\
& \text { urbane, zelene površine }) \\
\text { - } & \text { remediacija kontaminiranih površin }\left(\mathrm{m}^{2}\right) \\
\text { - } & \text { delež zaščitenih območij }\end{array}$ & $\begin{array}{l}\text { Katastrski načrti, } \\
\text { geodetske uprave, } \\
\text { kmetijski inštituti }\end{array}$ \\
\hline & Sprememba rabe tal & Geodetska uprava \\
\hline \multirow[t]{3}{*}{ Okolje } & $\begin{array}{l}\text { OBVEZNI SKUPNI * EVROPSKI INDIKATOR } \\
\begin{array}{cl}\text { A2 Lokalni prispevek h podnebnim spremembam } \\
-\quad & \text { emisije } \mathrm{CO}_{2} \text { na leto } \\
- & \text { emisije metana na leto } \\
- & \text { koncentracije } \mathrm{SO}_{2} \\
- & \text { koncentracije } \mathrm{NO}_{2} \\
-\quad & \text { izvor emisij } \mathrm{CO}_{2} \text { (posamezni energenti } \\
& \text { prodani v občini Selnica - premog, kurilno } \\
& \text { olje, plin, bencin, plinsko olje) - izračun } \\
\text { emisij } \mathrm{CO}_{2} \text { za posamezni energent v letu }\end{array} \\
\text { OBVEZNI SKUPNI * EVROPSKI INDIKATOR }\end{array}$ & $\begin{array}{l}\text { Zavod za zdravstveno } \\
\text { varstvo Maribor }\end{array}$ \\
\hline & $\begin{array}{l}\text { OBVEZNI SKUPNI * EVROPSKI INDIKATOR } \\
\text { A } 5 \text { kvaliteta lokalnega zraka } \\
\text { - kolikokrat letno so bile prekoračene vrednosti } \\
\text { onesnaženega zraka } \\
\text { - izdatki občine za zmanjševanje onesnaženega zraka }\end{array}$ & $\begin{array}{l}\text { Zavod za zdravstveno } \\
\text { varstvo, občina }\end{array}$ \\
\hline & $\begin{array}{l}\text { Uporaba obnovljivih virov energije v kmetijstvu in } \\
\text { gozdarstvu }\end{array}$ & EurObser ER, EUROSTAT \\
\hline \multirow{3}{*}{$\begin{array}{l}\text { Ravnanje } \mathrm{z} \text { odpadki } \\
\text { in odpadnimi } \\
\text { vodami }\end{array}$} & Distribucija občinskih odpadkov & Občina \\
\hline & Količine odpadne vode iz gospodinjstev, industrije & Občina \\
\hline & Generacija trdih/nevarnih odpadkov & Občina \\
\hline $\begin{array}{l}\text { Biotska } \\
\text { raznovrstnost }\end{array}$ & Območja visoke naravne vrednosti & $\begin{array}{l}\text { Inventar biotske } \\
\text { raznovrstnosti }\end{array}$ \\
\hline Pitna voda & $\begin{array}{l}\text { Kvaliteta vode } \\
\text { - koncentracije nitratov }(\mathrm{mg} / \mathrm{l}) \mathrm{v} \text { opazovalnih } \\
\text { aluvialnih vodonosnikih }\end{array}$ & ARSO \\
\hline Podtalnica & $\begin{array}{l}\text { Koncentracije ostankov fitofarmacevtskih sredstev } \\
\text { na opazovanih telesih podzemne vode } \mathrm{z} \text { medzrnsko } \\
\text { poroznostjo }\end{array}$ & SURS, FURS, KIS \\
\hline
\end{tabular}

* OBVEZNI SKUPNI EVROPSKI INDIKATORJI TRAJNOSTNEGA RAZVOJA IZHAJAJO IZ DOLOČIL EVROPSKE KOMISIJE - European common indicators - towerds a local sustainability profil, 2000 
V Sloveniji se uporablja sistem okoljskih indikatorjev Evropske okoljske agencije za potrebe evropskega poročila o okolju za leto 1998. Iz množice okoljskih indikatorjev Evropske okoljske agencije so izdvojili tiste, ki so za Slovenijo operativni. Pripravili so delovni seznam mednarodno primerljivih indikatorjev za spremljanje kakovosti gospodarske rasti (Radej 1999).

Leta 1992 so na Konferenci Združenih narodov o okolju in razvoju v Rio de Janeiru govorili o vzrokih za naraščajoče omejitve gospodarske rasti. Gospodarska rast je začela zaostajati zaradi prevelikega razvrednotenja okolja, ki ga povzroča sama. Netrajnostno rast naj bi ustvarjala rast ekonomskih dejavnosti iz neplačevanja stroškov razvrednotenja okolja, ki ga povzroča prekomerno izčrpavanje in obremenjevanje okolja. Najbolj ustaljeno merilo dinamike gospodarske rasti je bruto domači proizvod. Njegova uporabnost za potrebe merjenja kakovosti rasti je predvidoma toliko večja, kolikor boljše se DBP odreže pri merjenju zgolj gospodarske rasti. Že pri tem nastopijo težave, zlasti v tranzicijskih gospodarstvih in gospodarstvih z visoko inflacijo. Kljub vsemu je DBP indikator, ki je doslej doživel največ strokovne pozornosti in metodološkega razvoja, saj se izračunava po mednarodno primerljivih postopkih in je del sistema nacionalnih računov. Vendar za razliko od ekonomske vsebine DBP ne izraža enako dobro tudi trajnostne vsebine gospodarske rasti (Radej 1998, 8). Za vrednotenje rasti s stališča trajnosti DBP ni ustrezen pokazatelj, ker zajema predvsem tržne transakcije, presoje okoljskih razsežnosti rasti s stališča trajnosti razvoja pa segajo dlje kot na področje netržnih transakcij. DBP je izražen v denarnih enotah, okoljske značilnosti pa se izražajo tudi v nedenarnih enotah. DBP se uporablja za spremljanje razvoja v enem letu in to za nazaj, merilo trajnostnega razvoja pa bi moralo biti usmerjeno tudi vnaprej.

\section{ZAKLJUČEK}

Indikatorji so rezultat povezovanja različnih vsebin in pogledov. Cilj indikatorjev je, da prikažejo različne vsebine trajnostnega razvoja kolikor mogoče raznoliko, vendar strnjeno. Osnova indikatorjev je razmerje med vzrokom in posledico določenega stanja ali dejanja.

Indikatorji temeljijo na zastavljenih ciljih in prikazujejo različne statistično obdelane podatke. Vsebovati morajo opis samega indikatorja, področje, ki ga pokriva, zahtevan vir podatkov in biti morajo mednarodno primerljivi. Glede na bazo podatkov se določi tudi časovni interval spremljanja indikatorja.

Zaradi lažjega razumevanja indikatorjev in njihove uporabe gradimo indikatorje po sistemu trinivojske piramide. Nivoji predstavljajo različne nivoje ciljev za dosego trajnostnega razvoja in indikatorje za spremljanje teh ciljev:

- 1. nivo: indikatorji za spremljanje doseganja glavnega cilja - cilja strategije,

- 2. nivo: indikatorji za spremljanje izvajanja operativnih ciljev - cilji programov,

- 3. nivo: indikatorji za akcijske cilje - cilji projektov.

Osnovni nivo piramide so tako imenovani kontekstualni indikatorji, ki vsebujejo pomembne informacije in podatke, vendar neposredno ne merijo izvajanje oziroma doseganje ciljev. Različni nivoji imajo različno število indikatorjev in drugačne časovne intervale izvajanja. Indikatorji 3. nivoja se tudi lažje in hitreje spreminjajo in prilagajajo trenutnemu stanju. 
Proizvajanje in potrošništvo v naši družbi ni trajnostno naravnano. Dokazi za to nas spremljajo na vsakem koraku: soočamo se z vplivi podnebnih sprememb, z upadom biodiverzitete, s povečanjem razlik v materialnem in socialnem statusu med državami, kot tudi med regijami znotraj posamezne države.

\section{Viri in literatura}

Blue Plan, 2000. Indicators for sustainable development in the Mediterranean region, UNEP, Athens.

European Environment Information and Observation Network (EIONET).

http://www.eionet.eu.int/.

European common indicators - towards a local sustainability profil, 2000.

Environmental Assessment Report, No. 10, European Environment Agency.

Hans-Dietrich Hass, Dieter Matthew Schlesinge, 1997. Umweltoekonomie und Ressourcenmanagment. Wissenschaftliche Buchgesellschaft, Darmstadt, str. 14.

IB revija, št. 4, letnik XXXIV, Revija za trajnostni razvoj. UMAR, Ljubljana.

Plut, D., 2000. Environmental challenges of Europe: The state of environment and environmental trends in the EU (EU15) and Accession Countries (AC10). Geojournal 52, Kluweer Academic Publishers, 149-155.

Plut, D. 2002. Okoljevarstveni vidiki prostroskega razvoja Slovenije. Razprave Filozofske fakultete. Ljubljana, $292 \mathrm{~s}$.

Plut, D., Špes, M., Bračko, V. 2002. Slovenia. V: Environmental Problems of East Central Europe. Second editon. Edited by F.W. Carter and David Turnock. Routledge, London and New York, 229-247.

Plut, D., 1998. Varstvo geografskega okolja. Univerza v Ljubljani, Filozofska fakulteta, Oddelek za geografijo, Ljubljana.

Ravbar, M., 1999. Izbor indikatorjev regionalnega razvoja v funkciji proučevanja regionalnih disparitetkot prispevek k oblikovanju razvojne politike v R Sloveniji. IB revija št. 2-3, str. 68-81.

Radej, B., 2002. Delovna skica za opredelitev ekonomskih pojmov trajnostnega razvoja in razmerij med njimi. IB revija 4/2002, UMAR, str. 34.

Preliminary list of Sustainable Development Indikators Revision 2 (26/01/2004) - European Commission, Eurostat. Seveenth Meeting of the ESS Task Force on Methologocial Issues for Sustainable Development Indicators. SDI Workshop, 9-11th February 2004, Stockholm.

Radermacher, F.J., 2002. Balance oder Zerstoerung. Oekozoziale Marktwirtschaft als Schluessel zu einer weltweiten nachhaltigen Entwicklung. Oekosoziales Forum Europa.

Rejec Brancelj, I., Povše, U., 2003. Kazalci kot orodje za spremljanje okoljskega razvoja. MOP, Ljubljana.

Stategija prostorskega razvoja RS. 2003. Ministrstvo za okolje in prostor RS.

Tematska strategija za urbano okolje (2006) (http:/ec.europa.eu/environment/urban/hom en.htm) 
Priporočila za celostno okoljsko upravljanje. (http://www.eutrainingsite.com/ee_ programmes.php).

Treaty of Amsterdam amending the treaty on European Union, the Treaties establishing the European Communities and related actis. Official Journal C 340, 10 November 1997

A Sustainable for a better World: The European Sustainble Development Strategy 2001.

Brussels, 15.5. 2001. COM(2001) 264.

Ökologische Landentwicklung Steiermark. http://www.oele.steirmark.at/

Strateške presoje vplivov regionalnih razvojnih programov na okolje in programi Strukturnih skladov Evropske unije. Regionalni center za okolje za srednjo in vzhodno Evropo. Evropska komisija, Generalni direktorat za okolje. Prevajalec Roman Šimec. Regionalni center za okolje za srednjo in vzhodno Evropo, Ljubljana 2000.

Pečar, J., 2001: Regionalni vidiki razvoja Slovenije. Delovni zvezek 7/2002, UMAR, ARSO, Ljubljana.

Vintar, K., 2003. Okoljevarstveni vidiki sonaravnega regionalnega razvoja Slovenije. Magistrsko delo, Ljubljana.

Veliki slovar tujk, 2002. urednik Miloš Tavzes, cankarjeva založba, str. 492

http://www.un.org/esa/sustdev/natlinfo/indicators/isdms2001/table_4.html

http:/www.graz.at/umwelt/uamt/oekostadt/evaluirung.htm

\section{VIEW ON THE INDICATORS -FINGER FOR MEASURES OF SUSTAINABLE DEVELOPMENT}

\section{Summary}

Production and consumption in our society is not set sustainably. Evidence for that are with us at every step: we face impacts of climate changes, sinking of biodiversity, increasing of differences in material and social status between countries as well as between the regions in a country. Under the consideration of negative impacts that present development has on environment and nature the consideration of principles for sustainable development becomes more and more important. Sustainable development has become the necessity, which claims institutional, organizational and financial consistence. Society as whole should act in accordance with the principles of sustainable development.

Regional policies in different countries are not yet adjusted to the required changes, but it should be the objective of every country; the kind of development, that would reach improvement of life quality with economical, social and environmental progress in the framework of ecological limitations on planet Earth. The purpose of the development can not be the economical growth as it is, because we will exploit natural resources and threaten the realization of future generations' needs with aimless usage of different goods. That indicates that the usage of sustainable resources - in limitations, made possible by ecological capacity of a certain source - is an urgent condition of every sustainable development.

Human needs include beside many other elements also employment, education, health, accessibility to healthy natural environment, positive regional identity, responsible and co- 
operative government etc. Many developmental programs and orientations emphasize the necessity to help regions to reach their needs, where they would abolish unsustainable development and consumption approach, so they could replace it with approaches in favor of nature preservation. The most used definition of sustainable development is the definition of World Commission for Environment and Development from 1987, which says: "Sustainable development is the kind of development that satisfies present needs, without threatening possibilities of future generations to satisfy their own needs. Sustainable development is defined by three pillars: economic development, social and environmental development that needs to be in balance in order the society can develop in accordance with sustainable development objectives. We have to aim to the optimal, not excessive development of a particular pillar.

The indicators of sustainable development show the statistic values that measure the capacity of integral system for contentment of the needs for present and future generations. The indicators show the situation and the guidelines, how we pursue our goals. They are tools for progress measuring. Because they represent the most important information about deciding on the future ways of development, they have to be comprehensive and include information on all components of sustainable development: environment, economy, social or cultural view of development. They are meant for different users: the broader public, politicians, professionals, therefore they have to be prepared in a way to represent simplified information, which are relevant for reaching sustainable development.

The indicators are the result of connecting different contents and views. The aim of the indicator is to show different sustainable development contents as various as possible but joined. The base of the indicators is the proportion between the motive and the consequence of certain condition or action.

The indicators are based upon outlined objectives and show different statistically worked data. They have to contain the description of a certain indicator, covered area, required data source and have to be internationally comparable. Regarding to the data base the time interval of followed interval is defined as well.

Due to better indicator comprehension and their usage we build indicators upon the system of three-level pyramid. The levels represent different levels of objectives for attaining sustainable development and indicators to follow these objectives:

- Level 1: indicators for following the main objective - strategic objective

- Level 2: indicators for following the carrying out of operative objectives - program objectives

- Level 3: indicators for action objectives - project objectives

The basic pyramid levels are so called contextual indicators that include important information and data, but directly don't measure the completion or attaining of objectives. Different levels have different number of indicators and different time intervals of completion. Indicators of Level 3 are changed easily and faster and adjusted to the present condition. 